\title{
Pengukuran Pertumbuhan Volume Data Pada Sistem Informasi Pondok Pesantren
}

\author{
Muhammad Ainul Yaqin'1, Ahmad Ahya Ulhaq², Kevin Syafri Pratama ${ }^{3}$, Muhammad \\ Julkarnain" \\ Teknik Informatika, Universitas Islam Negeri (UIN) Maulana Malik Ibrahim Malang \\ Jl. Gajayana No. 50 Malang 65144 - Indonesia, Telp. +62 (341) 551-354 \\ yaqinov@ti.uin-malang.ac.id ${ }^{1}$, 16650092@student.uin-malang.ac.id²,16650126@student.uin- \\ malang.ac.id ${ }^{3}, 16650127 @$ student.uin-malang.ac.id ${ }^{4}$
}

\begin{abstract}
Islamic boarding school information system is a system that can launch a variety of boarding school management processes with available features. The boarding school system also facilitates all aspects involved in the estimation and management of the pesantren. Which aims to find out ways and get important information related to a boarding school. Growth related to the problem of growth measurement will change a volume of data to the growth of large changes in number and size. Regression is a statistical analysis method used to see the effect between two or more variables. These variables are connected with functional properties that are realized in a mathematical model. This paper explains in detail how to measure the growth of the volume of data available in Islamic boarding schools. Measurement of data volume growth in the Islamic boarding school information system consists of metric complexity, number of transactions and the size of the data. The three components are then processed through multiple linear regression and will then produce a picture in the form of modeling that can later show predictions of data volume growth.
\end{abstract}

Keywords: Information Systems, Data Volumes, Complexity Metrics, Regression

\begin{abstract}
Abstrak
Sistem informasi pondok pesantren merupakan suatu sistem yang dapat melancarkan berbagai proses manajemen pondok pesantren dengan fitur-fitur yang tersedia. Sistem pondok pesantren ini juga memudahkan segala aspek yang terlibat dalam hal perkiraan dan manajemen pesantren. Yang bertujuan untuk mengetahui cara dan mendapatkan sebuah informasi penting terkait sebuah pondok pesantren. Pertumbuhan yang berkaitan dengan masalah pengukuran pertumbuhan akan mengubah sebuah volume data pada pertumbuhan perubahan yang besar dalam jumlah dan ukuran. Regresi merupakan suatu metode analisis statistik yang digunakan untuk melihat pengaruh antara dua atau lebih variabel. Variabel-variabel tersebut terhubung dengan sifat fungsional yang diwujudkan dalam suatu model matematis. Paper ini menjelaskan secara detail bagaimana mengukur pertumbuhan volume data yang ada di pondok pesantren. Pengukuran pertumbuhan volume data pada sistem informasi pondok pesantren ini terdiri dari metrik kompleksitas, jumlah transaksi dan ukuran dari data tersebut. Dari ketiga komponen tersebut kemudian diproses melalui regresi linear berganda dan selanjutnya akan menghasilkan gambaran berupa pemodelan yang nantinya dapat memperlihatkan prediksi pertumbuhan volume data.
\end{abstract}

Kata kunci: Sistem Informasi, Volume Data, Metrik Kompleksitas, Regresi

\section{PENDAHULUAN}

Pondok pesantren merupakan sebuah asrama pendidikan tradisional yang ditempati oleh siswa atau lebih dikenal dengan sebutan santri tinggal bersama di bawah bimbingan dan didikan seseorang atau guru yang lebih dikenal dengan istilah kyai. Dimana pondok pesantren ini lahir di tengah-tengah masyarakat khususnya masyarakat islam. Didirikannya pondok pesantren bertujuan untuk memberikan pelajaran ilmu agama islam kepada para santrinya supaya bisa 
menjadi bekal untuk dirinya baik di dunia maupun akhirat, banyak pondok pesantren yang mencoba menyesuaikan diri akan suatu perubahan, namun ada juga pondok pesantren yang menutup diri dari pengaruh perkembangan teknologi saat ini.

Mengingat akan pesatnya kemajuan teknologi yang sudah merambah ke semua bidang, serta pola kehidupan masyarakat yang sudah relatif maju, dapat dipastikan hampir semua orang saat ini sudah memanfaatkan teknologi internet sebagai media penyampaian suatu informasi. Untuk mendapatkan informasi yang dibutuhkan, kita tidak perlu membuang waktu dan tenaga untuk datang ke tempat yang memiliki informasi tersebut, melainkan kita dapat memperoleh informasi hanya dengan mengakses internet dari manapun dan kapanpun asalkan tersedia layanan internet. Dengan adanya internet masyarakat dapat bertukar informasi dengan mudah dan cepat, tanpa harus bertemu di suatu tempat hanya untuk menyampaikan suatu informasi.

Sistem pengelolaan pondok pada kebanyakan pondok pesantren di Indonesia tidak terlalu memperhatikan aspek manajemen, model proses bisnis ataupun pertumbuhan data. Pada praktiknya sistem informasi pondok pesantren kebanyakan hanya memperhatikan data santri sebagai daftar santri pondok, tidak lebih. Kurangnya kesadaran dalam memproses data akan membuat rencana pondok pesantren tidak terarah. Sebenarnya jika diperhatikan lebih, data pada pondok pesantren dapat dimanfaatkan untuk memberikan keuntungan yang banyak pada pondok pesantren itu sendiri. Dengan data dan metrik, pihak pondok pesantren dapat memantau sudah sejauh mana pondok itu mencapai tujuannya, memprediksi anggaran yang lebih tepat, mengefisiensikan alokasi sarana dan prasarana pondok, pengoptimalan dalam pembelajaran dan sejumlah manfaat lainnya. Ada banyak macam serta jenis sistem informasi yang beredar di masyarakat, yang paling populer digunakan adalah sistem informasi manajemen pondok berbasis web yang dirasa penggunaannya mudah dan tidak memerlukan komputer dengan spesifikasi tinggi. Seharusnya aplikasi berupa sistem informasi pondok pesantren dapat membantu meningkatkan mutu kualitas pelayanan di pondok dan juga dapat membantu para pengambil keputusan secara cermat menetapkan kebijakan strategi yang dipergunakan untuk mencapai tujuan dari pondok pesantren.

\section{METODOLOGI PENELITIAN}

\subsection{Pondok Pesantren}

Pondok Pesantren merupakan rangkaian kata yang terdiri dari pondok dan pesantren. Kata pondok (kamar, gubuk, rumah kecil) yang dipakai dalam Bahasa Indonesia dengan menekankan kesederhanaan bangunannya. Ada pula kemungkinan bahwa kata pondok berasal dari bahasa arab "fundūk" yang berarti ruang tempat tidur, wisma, atau hotel sederhana [1]. Pesantren mulanya tersebar hanya di beberapa pedesaan. Namun, seiring berkembangnya zaman, pesantren mengalami modernisasi. Pesantren dulunya hanya sebagai tempat tinggal yang digunakan untuk menimba ilmu dengan cara berdekatan dengan sang pengajar atau kyai, sekarang pesantren dianggap sebagai lembaga pendidikan yang 
mencakup ruang lingkup yang kompleks, untuk memenuhi standart nasional pondok pesantren, butuh beberapa proses pengembangan arsitektur data sistem informasi pondok pesantren agar menjadi lembaga pendidikan islam yang memadai.

\subsection{Sistem Informasi}

Sebuah sistem dimana di dalam suatu organisasi yang meliputi kebutuhan pengolahan transaksi harian, mendukung operasi, bersifat manajerial dan kegiatan strategi dari suatu organisasi dan menyediakan pihak luar tertentu dengan laporan-laporan yang diperlukan merupakan definisi dari sistem informasi [2]. Dapat disimpulan sistem informasi adalah sebuah software, hardware, data dan jaringan komunkasi yang terorganisasi untuk mengumpulkan, memasukkan, mengolah, mengendalikan, menyimpan data dan melaporkan infromasi untuk dapat mendukung pengambilan keputusan atau tujuan suatu organisasi tersebut.

\subsection{Metrik Skala Kompleksitas Class Diagram}

Metrik skala kompleksitas class diagram merepresentasikan tingkat kerumitan class yang digambarkan dengan class diagram pada suatu program. Pada dasarnya, sebuah program adalah serangkaian method yang dapat dieksekusi yang mengambil data sebagai input, melakukan pemrosesan, dan kemudian memberikan hasil yang diinginkan. Upaya aktual atau fondasi pemrograman difokuskan pada cara menulis logika daripada definisi data. O0P yang terutama menekankan bahwa object dalam paradigma pemrograman adalah object yang harus diubah sesuai dengan kebutuhan dan penggunaan kita dan bukan logika yang diperlukan di balik manipulasinya[3]. class terdiri dari method (Method), atribut (Attribute), dan relasi (Relation). Sehingga, metrik skala dan kompleksitas class diagram dapat diformulasikan sebagai berikut[4]:

$$
\begin{aligned}
\text { Class }= & \left(0.637 \cdot \sum \text { Method }\right) \\
& +\left(0.258 \cdot \sum \text { Attribute }\right) \\
& +\left(0.105 \cdot \sum \text { Relation }\right)
\end{aligned}
$$

\subsection{Metrik Skala Kompleksitas Method}

Metrik skala kompleksitas method merepresentasikan tingkat kerumitan method pada suatu class. Kompleksitas method ditentukan oleh skala kompleksitas alur program yang direpresentasikan menggunakan flowchart. Namun berdasarkan batasan masalah, perhitungan dilakukan dengan mengabaikan kompleksitas method, sehingga diasumsikan kompleksitas setiap method bernilai 1.

\subsection{Metrik Skala Kompleksitas Attribute}

Metrik skala kompleksitas attribute merepresentasikan tingkat kerumitan atribut-atribut pada suatu class. skala kompleksitas attribute ditentukan berdasarkan tipe data (DT) dan lebar datanya (DW). Setiap tipe data memiliki bobot tertentu berdasarkan tabel 1 [4]. 
http://tunasbangsa.ac.id/ejurnal/index.php/jurasik

Tabel 1. Tipe Data dan Bobot
\begin{tabular}{|l|c|}
\hline \multicolumn{1}{|c}{ Tipe Data } & Bobot \\
\hline Bit & 0.01 \\
\hline Tinyint, year & 0.06 \\
\hline Smallint & 0.11 \\
\hline Char, binary, tinytext, tinyblob & 0.12 \\
\hline Text, blob, varchar, varbinary & 0.16 \\
\hline Mediumint, time & 0.17 \\
\hline Int, float, timestamp & 0.22 \\
\hline Mediumtext, mediumblob & 0.24 \\
\hline Bigint, double, decimal, real, numeric, datetime, time & 0.44 \\
\hline Longtext, longblob & 0.48 \\
\hline
\end{tabular}

Skala kompleksitas Attibut dapat diformulasikan sebagai berikut:

$$
\text { Attribute }=D T \cdot D W
$$

\subsection{Metrik Skala Kompleksitas Relation}

Metrik skala kompleksitas relation merepresentasikan tingkat kerumitan relasi antara class satu dengan yang lain pada suatu class diagram. Kompleksitas Relasi (Relation) dalam class diagram didapatkan dari penjumlahan berbagai tipe relasi yang ada dalam class diagram tersebut. Jenis-jenis relasi yang ada dalam class diagram adalah Inheritance, Association, Composition, dan Aggregation. Skala kompleksitas relation dapat diformulasikan sebagai berikut[4]:

Relation $=(a \cdot$ Inheritance $)+(b \cdot$ Association $)+(c \cdot$ Composition $)+$ $(d \cdot$ Aggregation $)$

\subsection{Analisis Kuadran}

Importance Performance Analysis (IPA) atau biasa disebut Analisis Kuadran adalah suatu teknik analisis deskriptif yang diperkenalkan oleh John A. Martilla dan John C. James tahun 1977. Analisis Kuadran adalah suatu teknik analisis yang digunakan untuk mengidentifikasi faktor-faktor kinerja penting apa yang harus ditunjukkan oleh suatu organisasi dalam memenuhi kepuasan para pengguna jasa mereka (konsumen) [5].

\subsection{Regresi Linier Berganda}

Metode regresi linier berganda adalah salah satu jenis metode regresi yang merupakan teknik analisis yang menjelaskan hubungan antara dua peubah atau lebih khususnya antara peubah-peubah yang mengandung sebab akibat disebut analisis regresi [6]. Sehingga dalam kaitannya dengan uraian tersebut diatas, penelitian ini bertujuan untuk mengetahui peramalan pertumbuhan volume data dengan menggunakan metode regresi linear berganda pada sistem informasi pondok pesantren.

\section{HASIL DAN PEMBAHASAN}

Pada bagian ini diberikan hasil penelitian yang dilakukan sekaligus membahas secara komprehensif. Hasil dapat berupa gambar, grafik, tabel dan lain- 
lain yang mempermudah pembaca paham dan diacu di naskah. Jika bahasan terlalu panjang dapat dibuat sub-sub judul, seperti contoh berikut.

\subsection{Analisa Pengukuran menggunakan Regresi linier}

Tabel 2. Tabel Variabel Entered

\begin{tabular}{|c|c|c|}
\hline R & R Square & Adjusted R Square \\
\hline-919 & -945 & -942 \\
\hline
\end{tabular}

Untuk memperkirakan Asosiasi antara variabel independen yang diberikan dan hasil memegang semua variabel lain konstan, menyediakan cara untuk menyesuaikan (atau akuntansi untuk) berpotensi konfounding variabel yang telah dimasukkan dalam model. Regresi linier berganda untuk mengetahui hubungan kausal antara variabel Terikat dan variabel pertumbuhan. Rumusnya adalah:

$$
\mathrm{Y}=\beta 0+\beta 1 \mathrm{X} 1+\beta 2 \mathrm{X} 2+\beta 3 \mathrm{X} 3+\beta 4 \mathrm{X} 4+\beta 5 \mathrm{X} 5
$$

Nilai koefisien determinasi (R-Square) yang diperoleh adalah 0.622 , memiliki arti bahwa keragaman perubahan data pada pondok pesantren yang dapat dijelaskan oleh tangible, empathy, reliability, responsiveness dan assurenace adalah sebesar $62.2 \%$ dan sisanya $37.8 \%$ dipengaruhi oleh variabel lain selain variabel yang digunakan dalam model regresi. Sementara itu nilai R menunjukkan besarnya hubungan antara tangible, empathy, reliability, responsiveness dan assurance tergolong kuat karena nilainya sudah lebih besar dari 0.50 .

Untuk mengetahui pengaruh secara simultan variabel bebas terhadap variabel terikat digunakan uji F. Dengan ketentuan jika F hitung $>$ F tabel pada tingkat signifikansi $0.05 \quad(\alpha=5 \%)$, maka variabel bebas secara simultan berpengaruh signifikan terhadap variabel terikat.

\subsection{Analisa Pengukuran menggunakan Analisa Kuadran}

Analisis kuadran digunakan dalam hubungannya dengan variabel Terikat dengan variabel pertumbuhan, survei variabel pembangunan, dan survei pertumbuhan pondok pesantren untuk menganalisis kesenjangan antara penurunan dan peningkatan yang sebenarnya. Hasilnya dapat membantu kami mengidentifikasi area untuk perbaikan. Range sumbu x dan y didasarkan pada nilai indikator yang paling kecil sampai pada yang paling besar. Pada sumbu x yang mewakili I, nilai paling kecil adalah 5.427 dan nilai paling besar adalah 0.681 . Sedangkan pada sumbu y yang mewakili RI, nilai paling kecil adalah -1.291 dan nilai yang paling besar adalah 0.916. Berikut adalah kelompok indikator berdasarkan tiga faktor kepentingan.

a) Indikator yang termasuk dalam basic factors antara lain ialah RE1.3, A1.1, RE1.1, dan R1.1.

b) Indikator yang termasuk dalam performance factors antara lain ialah T1.2, RE1.2, E1.1, RE1.5, E1.2, RE1.4, E1.4, T1.5, A1.4, R1.3, T1.1, R1.2, dan T1.4.

c) Indikator yang termasuk dalam excitement factors antara lain adalah T1.3, A1.3, A1.2, dan E1.3. 
Berdasarkan hasil analisa kuadran dapat diketahui bahwa indikator penelitian: kesesuaian antara data awal dan data pertumbuhan yang didapatkan, Secara perhitungan pondok pesantren mengalami pertumbuhan, prestasi yang didapat mengakibatkan beberapa calon murid menjadi tertarik dengan kualitas sekolah, dan dari segi pembelajaran dalam hal proses pembelajaran juga berpengaruh signfikan. Hal ini mengindikasikan bahwa indikator - indikator diatas harus dimiliki oleh beberapa pondok pesantren lainnya dimana data diatas merupakan kebutuhan minimal yang harus dimiliki pondok pesantren dalam pemenuhan peningkatan kualitas pembelajaran.

Hasil analisa kuadran juga didapatkan indicator-indikator yang termasuk dalam Performance Factors, jadi jumlah kelas yang memadai, fasilitas sekolah yang mumpuni, serta kemampuan guru untuk mengajar juga di perhitungkan, kejelasan apa yang dipelajari. Indikator-indikator yang termasuk dalam kualitas faktor diatas dapat berujung kepada kepuasan atau ketidakpuasan santri, mengikuti dari kualitas penyampaian yang dilakukan pondok pesantren. Apabila indicatorindikator disampaikan dengan baik kepada santri, maka dapat menimbulkan peningkatan kualitas santri, sebaliknya apabila tidak disampaikan dengan baik atau mengecewakan, maka dapat menimbulkan penurunan kualitas.

Tabel 3. Hasil uji F

\begin{tabular}{|c|c|c|c|c|c|}
\hline Model & Sum Of Squares & Df & $\begin{array}{c}\text { Mean } \\
\text { Square }\end{array}$ & $\begin{array}{c}F \\
\text { Hitung }\end{array}$ & sig \\
\hline Regresion & 38.012 & 19 & 2.001 & 7.724 & 0 \\
\hline Residual & 10.879 & 42 & 0.259 & & \\
\hline Total & 48.891 & 61 & & & \\
\hline
\end{tabular}

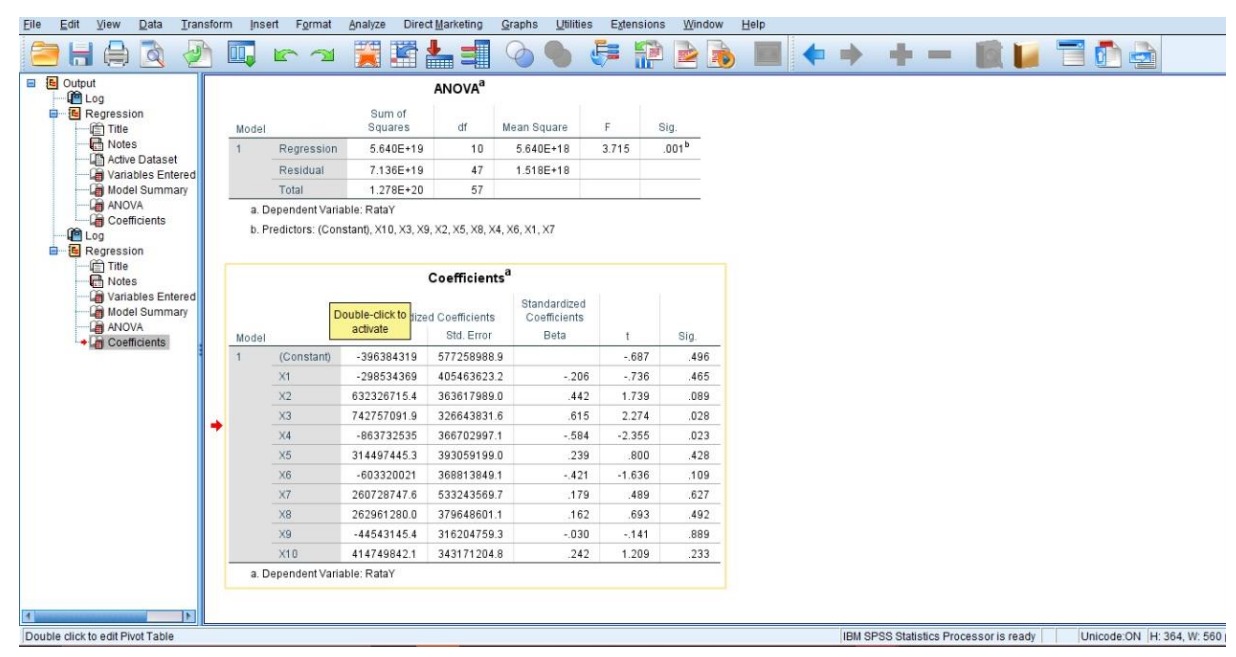

Gambar 1. Analisa Kuadran 


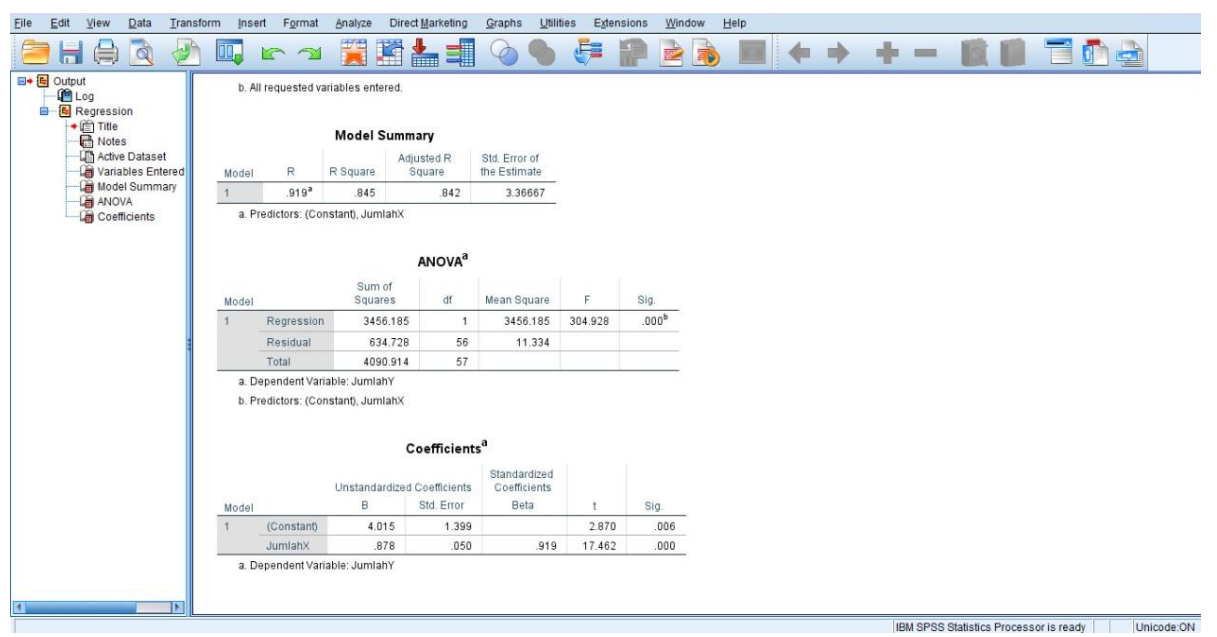

Gambar 2. Regresi Linier

Pada Tabel 3. menunjukkan bahwa hasil uji $\mathrm{F}$ menghasilkan $\mathrm{F}$ hitung sebesar 48.891 lebih besar dari nilai F tabel 7.724 (df1=19, df2=42, $\alpha=0.05$ ). Berdasarkan hasil tersebut dapat disimpulkan bahwa Pertumbuhan Volume yang terdiri Jumlah, reliability, responsiveness dan assurenace berpengaruh secara signifikan terhadap santri pada pondok pesantren.

\begin{tabular}{|c|c|c|c|c|c|c|c|c|c|c|c|}
\hline \multicolumn{12}{|c|}{$\begin{array}{c}\text { Tabel 4. Hasil Uji t } \\
\text { Coefficients }^{\mathrm{a}}\end{array}$} \\
\hline \multirow[b]{2}{*}{ Mode } & & \multicolumn{2}{|c|}{ Unstandardized Coefficients } & \multirow{2}{*}{$\begin{array}{c}\text { Standardized } \\
\text { Coefficients } \\
\text { Beta }\end{array}$} & \multirow[b]{2}{*}{$t$} & \multirow[b]{2}{*}{ Sig. } & \multicolumn{3}{|c|}{ Correlations } & \multicolumn{2}{|c|}{ Collinearity Statistics } \\
\hline & & B & Std. Error & & & & Zero-order & Partial & Part & Tolerance & VIF \\
\hline \multirow[t]{20}{*}{1} & (Constant) & -.196 & .455 & & -.431 & .669 & & & & & \\
\hline & V2 & -.040 & .155 & -.042 & -.257 & .798 & .195 & -.040 & -.019 & .199 & 5.013 \\
\hline & $\mathrm{V}_{4}$ & .035 & .141 & .036 & .245 & .808 & .210 & .038 & .018 & .246 & 4.067 \\
\hline & V5 & -.005 & .144 & -.005 & -.035 & .972 & .244 & -.005 & -.003 & .231 & 4.323 \\
\hline & V6 & -.115 & .167 & -.118 & -.686 & .496 & .280 & -.105 & -.050 & .178 & 5.626 \\
\hline & V7 & -.173 & .118 & -.182 & -1.462 & .151 & .246 & -.220 & -.106 & .343 & 2.914 \\
\hline & V8 & .210 & .183 & .222 & 1.146 & .258 & .512 & .174 & .083 & .142 & 7.065 \\
\hline & V9 & .009 & .118 & .010 & .080 & .937 & .367 & .012 & .006 & .336 & 2.972 \\
\hline & V10 & -.048 & .134 & -.051 & -.361 & .720 & .342 & -.056 & -.026 & .267 & 3.740 \\
\hline & V11 & -.109 & .123 & -.114 & -.888 & .380 & .069 & -.136 & -.065 & .320 & 3.125 \\
\hline & V12 & .022 & .065 & .146 & .337 & .738 & .458 & .052 & .024 & .028 & 35.290 \\
\hline & V14 & -.615 & .139 & -.655 & -4.430 & .000 & .427 & -.564 & -.322 & .243 & 4.120 \\
\hline & V16 & -.476 & .119 & -.512 & -3.985 & .000 & .404 & -.524 & -.290 & .320 & 3.120 \\
\hline & V17 & -.344 & .112 & -.362 & -3.082 & .004 & .313 & -.429 & -.224 & .384 & 2.601 \\
\hline & V18 & -.711 & .152 & -.739 & -4.667 & .000 & .112 & -.584 & -.340 & .211 & 4.734 \\
\hline & V19 & -.437 & .151 & -.442 & -2.895 & .006 & .290 & -.408 & -.211 & .227 & 4.403 \\
\hline & $\mathrm{V} 20$ & -.659 & .178 & -.684 & -3.698 & .001 & .364 & -.496 & -.269 & .155 & 6.452 \\
\hline & V21 & -.552 & .149 & -.575 & -3.697 & .001 & .287 & -.496 & -.269 & .219 & 4.569 \\
\hline & V22 & -.373 & .125 & -.384 & -2.979 & .005 & .366 & -.418 & -.217 & .318 & 3.144 \\
\hline & $\mathrm{V} 23$ & .529 & .068 & 3.182 & 7.752 & .000 & .649 & .767 & .564 & .031 & 31.809 \\
\hline
\end{tabular}

\subsection{Metode Gap}

Analisis kesenjangan adalah proses yang pembandingkan kinerja atau hasil aktual dengan apa yang diharapkan atau diinginkan. Metode ini menyediakan cara untuk mengidentifikasi strategi, struktur, kemampuan, proses, praktik, teknologi, atau keterampilan yang kurang optimal atau hilang, dan kemudian merekomendasikan langkah-langkah yang akan membantu pondok pesantren untuk mencapai tujuannya. 


\subsection{Kompleksitas Pertumbuhan Volume}

Kompleksitas memiliki parameter kombinasi dari rumus yang telah dibahas diatas. Masing-masing persamaan dikalikan dengan suatu variabel yang telah ditentukan.

Berikut persamaannya :

$$
\begin{aligned}
\text { Kompleksitas } & =A . X+B . Y+C \\
& =48.891 \times 7+7.724 \times 9+942 \\
& =412.695
\end{aligned}
$$

\section{SIMPULAN}

Dengan menggunakan beberapa metode dan perhitungan didapatkan bawah pesantren akan bertumbuh jika ada beberapa faktor yang diperhatikan. Dari hasil perhitungan, diperoleh kesimpulan bahwa Sistem Informasi Pondok Pesantren diatas memiliki tingkat kompleksitas kode sebesar 412.695 .

\section{DAFTAR PUSTAKA}

[1] Muhammad Idris Usman, "PESANTREN SEBAGAI LEMBAGA PENDIDIKAN ISLAM", Jurnal Al Hikmah, Vol. XIV, No.1, pp 102, 2013.

[2] Hartono, J., "Analisis dan Desain Sistem Informasi”, ANDI, 2005.

[3] Urdhwareshe, A., "Object-Oriented Programming and its Concepts", Innovative Space of Scientific Research Journals, Bridgeport, 2016.

[4] Lanza, M., Marinescu, R., Ducasse, S., “Object-Oriented Metrics in Practice: Using Software Metrics to Characterize, Evaluate, and Improve the Design of ObjectOriented Systems", Springer Science \& Business, 2006.

[5] John A. Martilla and John C. James, "Importance-Performance Analysis", Journal of Marketing, pp 77-79, January 1977.

[6] Margaretha G. Mona, John S. Kekenusa, Jantje D. Prang, "Penggunaan Regresi Linear Berganda untuk Menganalisis Pendapatan Petani Kelapa Studi Kasus: Petani Kelapa Di Desa Beo, Kecamatan Beo, Kabupaten Talaud", JdC, Vol. 4, No. 2, pp 197, September 2015. 